\title{
ICL in UK Tertiary Education: The case of German
}

Abstract:

In many European universities, the second language (L2) English is used to teach nonlinguistic disciplines such as business or engineering. In anglophone UK, integration of content and language (ICL) generally features in Modern Languages undergraduate programmes where content is taught through the $L 2$ to maximise exposure. However, few programmes employ a structured approach, and there is currently little research on ICL in UK universities.

This paper reports on the extent to which German is used as the medium of instruction in UK undergraduate German programmes and discusses the institutional parameters which influence the integration of content and language. It appears that the practice of teaching subject-specific content in the target language is more wide-spread than previously thought. Content provision in the $L 2$ is in fact quite common, but the extent, timing, and purpose of ICL depend on the type of university.

\section{Introduction}

The past decades have seen a remarkable proliferation of research in educational settings where a second language is used as medium of instruction in higher education. Some countries - the Netherlands, Finland, Spain, to name but a few - have clearly led the way in this endeavour to investigate the integration of content and language in Higher Education $(\mathrm{HE})$, mainly featuring English as the language of instruction. Anglophone UK is - perhaps understandably - characterised by a dearth in ICL research which may indicate that CLIL ${ }^{1}$ is far less common in British tertiary education than in the rest of Europe.

This paper reports on the findings of an empirical study investigating German departments across Britain to determine how widespread L2-medium instruction is in undergraduate (UG) content modules. Reasons for - and against - ICL and institutional parameters which foster or hinder - its implementation are discussed. In order to set the scene, we first give a short overview of the current situation in the UK modern languages landscape and provide a brief introduction to German Studies in the UK.

\footnotetext{
${ }^{1}$ While ICL and CLIL differ slightly in their origin, geographical application, institutional implementation and didactic-theoretical framing (cf. Gustafsson et al. 2011), both are based on the idea that an L2 is used in the teaching of subjects other than the language itself. In the UK context, the term ICL is virtually unknown; instead, CLIL is used to describe educational scenarios across the spectrum, from primary to tertiary education. Accordingly ICL and CLIL will be used interchangeably in this paper.
} 
II. Integrating content and language study in higher education

There is clear evidence for the growing proliferation of ICL in non-Anglophone European higher education, where the number of English-taught BA, MA and PhD programmes has increased exponentially and where such settings have become the subject of numerous academic investigations. In these cases, English is generally used as the medium of instruction in non-linguistic disciplines for various reasons: to support internationalisation, to increase student mobility and foster employability for domestic students, to attract international students and staff, etc. (cf. Coleman 2006, pp. 1-14)

In UK higher education, L2-taught content teaching settings have received far less research interest, at least with regard to languages other than English (LOTE). There is little evidence that LOTE play a significant role as a medium of instruction in the UK, or in continental Europe, for that matter. ${ }^{2}$ This despite the fact that there is at least one subject which seems predestined to serve as a setting for CLIL, namely modern foreign languages. The close relationship between the target language and the culture and community of its speakers would seem to make MFL a natural fit for ICL; after all, r̃culture in its broadest sense is inseparable from languageò(Coleman 1996, p. 17).

There are some case studies which describe CLIL-type setups at individual UK university departments, published online as part of the Subject Centre for Languages, Linguistics and Area Studies (LLAS) Guide to Good Practice (cf. Macías 2006, Tamponi 2005). Among the more general research output investigating MFL in UK higher education, there are some studies which look at the relationship between language and content, although they do not explicitly refer to CLIL or ICL (cf. McBride 2003, Gieve \& Cunico 2012). Still, the relative lack of research interest in L2-medium instruction would indicate that the ICL is far less common than one would expect.

\section{The British MFL landscape today}

It is widely known that student numbers in Modern Language degree programmes have been declining for a number of years. Grix and Jaworska (2002, pp. 4-5) posit that ர̃a] lack of qualified teachers and low motivation among those teaching are [...] contributing factors to the state of language learning in UK schoolsò along with ñimited contact with the language and cultureò Student motivation for learning MFL seems to have been at an alarming low for quite some time: At the turn of the millennium, the Nuffield Language Inquiry found that nine out of ten children stopped learning languages at 16 (Nuffield Foundation 2000). The situation further escalated when, in 2004, foreign languages became optional after age 14 in

\footnotetext{
${ }^{2}$ With the exception of minority languages, for example in the autonomous regions of Spain and in Wales, to name just a few.
} 
secondary state schools. Since modern languages were no longer mandatory post-14, GCSE $^{3}$ entries in German declined by $51.7 \%$ between 2003 and 2011 (Tinsley \& Han 2012, p. 12). Subsequently, even fewer students have pursued MFL to A-level since 2004: The total number of A-level entries for languages across England fell by $26 \%$ between 1996 and 2011, while figures for German (and French) dropped by approximately 50\% (ibid., pp. 1213). Consequently, many university language departments struggle to draw a significant number of qualified students to their language degrees.

This development has been exacerbated by the recent trebling of university fees to up to $£ 9,000$ per annum. In the first application cycle under the new fees regime (January 2012), the number of applications for European languages was down by $11.2 \%$; the numbers for German Studies specifically decreased by $23 \%$ (UCAS 2012). In January 2013, applications for European Languages again decreased by $6.1 \%$. And while the figures for German have

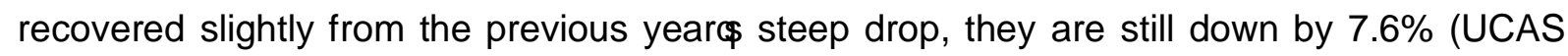
2013, p. 5).

These admission trends put increasing financial pressure on university departments, as a decrease in students means reductions to university funding. In order to still make teaching provision financially viable, departments are looking for ways to increase efficiency, which helps explain the current trend of making them accessible to students without the requisite language skills, e.g. from other MFL, politics or history departments, by teaching in English. However successful a strategy, making course content available to non-linguists, e.g., by teaching texts in translation, to bolster student numbers was found to have both academic and affective consequences: According to Worton (2009, p. 25), it was r̃generally perceived as a form of đ́lumbing downôor even a betrayal of the nature and aims of a Modern Foreign Languages curriculumò

The growing share of curricula being taught in English due to - mostly financial - pressures is only one side of the story. Over the last decades, experts have observed a national trend away from Single Honours degrees (Footitt 2005, p. 9), and even dual language degrees are losing ground (Klapper 2006, p. 2). Integrated degrees which combine a language and another non-linguistic discipline are still popular, but increasingly, universities rãre offering programmes in which a language is an optional rather than compulsory componentò(Kelly \& Jones 2003, p. 24). The high costs of delivering MFL programmes, combined with falling student numbers, mean that many language departments are in deficit and require crosssubsidy by other parts of the university. Ultimately, fluctuating admissions numbers have led to a wave of MFL Department closures and to the concentration of MFL in certain universities.

\footnotetext{
${ }^{3}$ GCSE $=$ General Certificate of Secondary Education, marks the end of compulsory education at 16.
} 
The reasons behind this general decline of MFL Studies are difficult to understand, especially in light of the many voices from both academia and the private sector decrying the distinct lack of qualified MFL experts. To give but two examples, a report on the British labour market $\hat{\Phi}$ demand for modern language graduates published in 2011 highlighted the urgent need for linguistically proficient, well-rounded language specialists in the UK. The report found that the European Big4ôFrench, German, Spanish and Italian remain most in demand by employers specifying a language for recruitment, and that higher education played a significant role in closing the skills gap caused by a decrease in German uptake post-GCSE. In fact, recruitment agencies reported that in the previous 12 months, German was the most requested language, with more than 1,500 jobs requiring German, about $25 \%$ of the total (Mulkerne \& Graham 2011, p. 38). More recently, the British Council published a report which found that the UK needs to develop its citizensôcompetence in a wider range of languages, and in far greater numbers, in order to reap the economic and cultural benefits available to those who have these skillsòand calls for ra strategic approach in planning for effective development of the capacityòthe UK needs (Tinsley \& Board 2013, p. 3).

\section{German Studies in the United Kingdom}

Beginning in the $19^{\text {th }}$ Century, German was the most widely taught modern foreign language in Great Britain, after French, until very recently, when it was overtaken by Spanish (Reershemius 2010, p. 1674). After a decline in the interwar years, German gained strength after World War 2, despite a general decrease in MFL numbers overall. Following a brief boom in German uptake in the wake of German re-unification in the early 1990s, numbers have declined steadily since then. Today, German Studies in Britain is a discipline in crisis. Inevitably, German at the tertiary level is facing similar challenges to lower-level education, in that the number of undergraduate students has fallen continuously - by 33\% between 1997 and 2006/07 (ibid., p. 1678). Ultimately, this trend has led to a wave of department closures: Where 126 universities in Great Britain offered German undergraduate programmes in 2000, their number had fallen by $48 \%$ to 65 by 2006 (ibid., p. 1677).

German Studies programmes at different types of universities can vary greatly with regard to their thematic focus. đypeôhere is a purely descriptive term and is mainly determined by the age of the university, i.e. when it was founded or chartered. Therefore, Ancient university describes institutions founded before 1800, Red Brick university means chartered in the $19^{\text {th }}$ and early $20^{\text {th }}$ century, Plate Glass universities were chartered between the 1960 s and 1992 , New university describes post-1992 institutions, and Recently created universities have been granted university status since $2005 .^{4}$

\footnotetext{
${ }^{4}$ These categories are commonly used to describe UK universities which share certain historically developed institutional, educational and research characteristics.
} 
By and large, a shift in conceptual focus initially occurred in the 1960s and coincided with a wave of technical colleges being re-designated and new universities being founded. Many MFL programmes moved away from the traditional model of a rather literature-heavy syllabus which involved the study of the diterary greatsôthroughout the centuries, towards a more contemporary, vocational model and a broader socio-cultural curriculum, influenced by new disciplines such as Area Studies, Cultural Studies and Media Studies. This reorientation was partly due to the growing impact of student choice on curriculum design. The growing commercialisation of higher education, brought about by the introduction of university fees, has meant that student interests have come to exert considerable influence on the design and implementation of MFL degree programmes. Those institutions founded or chartered after WW2 are especially characterised by a strong utilitarian focus on employability, and their curricula are designed accordingly.

One apparent consequence of this re-orientation is highlighted by Kolinsky in a study of developments in UK German Studies in the early 1990s: Her survey showed that $77 \%$ of participating departments taught content in German, and an additional 15\% reported that German was used to teach selected modules, while only $8 \%$ refused to teach content in German (Kolinsky 1994, p. 42). Judging from these findings, the use of German as a medium of instruction appears to have a longer tradition in the UK than previously thought. It clearly has been recorded incidentally in research describing the development and status of German Studies in the UK, but has not been the object of academic investigation itself. The following section outlines an empirical study, based on an online survey of German undergraduate programmes, providing an updated picture of the extent to which German functions as a medium of instruction today and discusses the reasons for and institutional parameters underlying the integration of content and language in German in UK tertiary education.

\section{ICL in German undergraduate teaching: Empirical findings}

In order to investigate the current proliferation of ICL in British higher education, a short online survey was administered to Heads of German staff at British universities to elicit information about institutional parameters which may influence the implementation of targetlanguage content teaching.

\section{Method}

A 10-question online survey was sent to all British universities which offer German as a Single Honours degree or as part of a Joint or Combined Honours degree, as they were more likely to feature modules which were content-based rather than purely languageoriented. The survey was submitted by email to 51 German departments at UK universities, 
with a response rate of $55 \%$. The data collected from these 28 university departments allows us to determine the extent to which L2-content teaching is practiced, and the institutional contexts in which it takes place.

Institutional profiles

Of the 28 German departments across England, Wales and Scotland participating in the survey, the majority (54\%) of respondents fall in the category of Red Brick university, followed by Plate Glass universities (21\%) and New universities (14\%). Ancient universities account for $11 \%$, and one (4\%) is a Recently created university. The vast majority, or $79 \%$, of German sections are positioned within a MFL department; $11 \%$ of German groups are situated within a MFL department combined with Politics, Social Sciences, etc. The same number represents individual Schools or Departments of German. Of these, two are ǿlderô universities, that is, those founded or chartered before World War 2, and only one represents a ónewerôuniversity (Plate Glass). $82 \%$ of respondents stated that their German degrees include a mandatory Year Abroad.

\section{Extent of $L 2$ content teaching}

The second half of the survey relates directly to L2-content teaching. Overall, $68 \%$, or 19 of 28 respondents, reported that some content modules in their German programmes are taught in German.

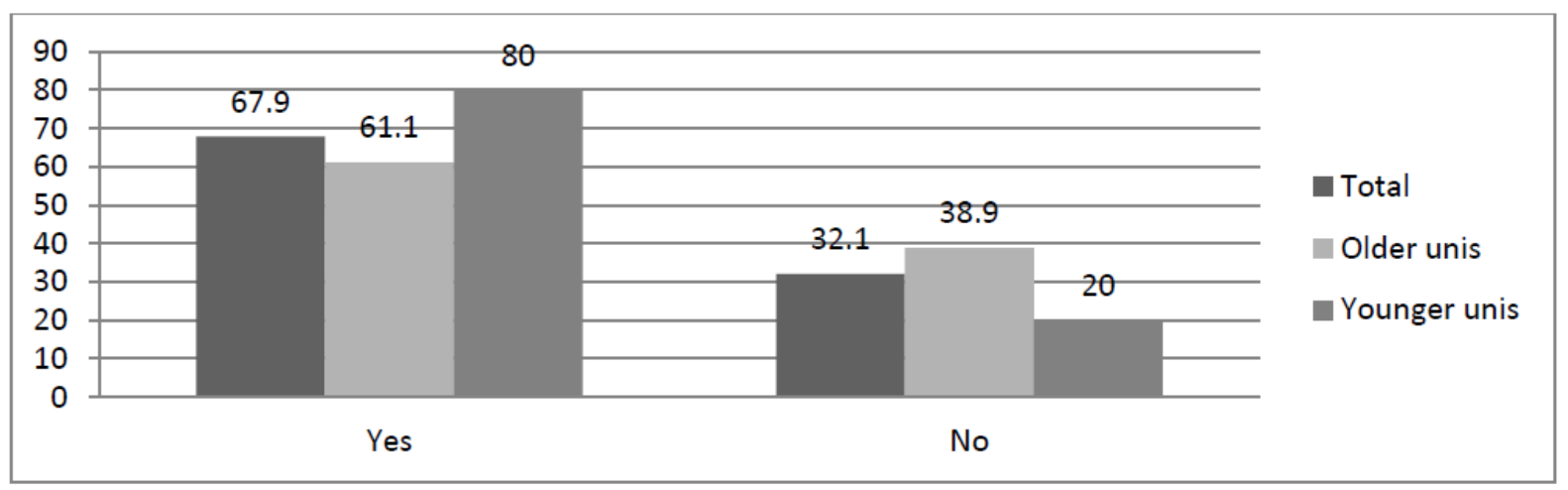

Fig. 1: Question 5, ñAre any of the content modules in your German programmes taught in German?ò

If we correlate these figures with the type of university to see whether the age of an institution is a factor in the decision to introduce L2 content teaching, the results show that two of the three Ancient universities teach content in the L2, as do $60 \%$ of Red Brick universities, $83 \%$ of Glass Plate universities and $75 \%$ of New and Recently created universities. Therefore, generally speaking, older universities seem to feature less targetlanguage content teaching than the more recently founded institutions. 
Overall, these figures are rather surprising, as this apparent proliferation of L2 content teaching has garnered little research interest until now, which could indicate that CLIL practice at many universities is sometimes incidental. A comment added by Respondent \#12 supports this hypothesis: Whe leave it up to individual staff to decide.ò In this case, it is impossible to know whether any reflection on the specific requirements of effective CLIL implementation is taking place. When that happens, ñhere is a risk that the language will be considered as purely instrumentalò(Costa 2009, p. 84) and the potential benefits are greatly reduced.

Reasons for and against introducing target-language content instruction

There are indications that some universities are considering the introduction of L2 content teaching: Of those German departments (32\%) where no content modules ${ }^{5}$ are currently taught in German, 33\% state that there are plans to introduce L2-taught modules. The added comments bring up three interesting aspects which may have considerable impact on the future of CLIL in British HE. Two respondents remarked that teaching content in German had actually been discontinued in order to rälow students from other Schools (mainly Politics and History) tochoose [sic] German content unitsò (Respondent \#7). This is echoed by Respondent \#15 who explains: ñn the current climate there is more emphasis on making content units available to students without German [...]. Teaching in the target language would militate against interdisciplinarity.ò

Still, the comments are not all doom and gloom: Some departments are going the other way by introducing more German-taught content teaching. Respondent \#20, for example, states that ñhe European culture lectures are at the moment shared with students of French, Spanish and European Studies and therefore, taught in English. However, from next year they will be taught separately in the specific target languages, e.g. also German.ò The

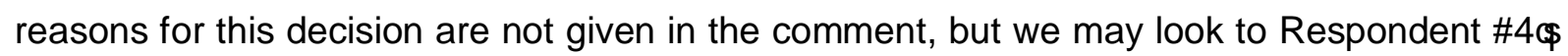
comment for possible explanations: r̃Current discussions are taking place over the introduction of some content teaching in the target language (traditionally this has not been the case) - partly due to student demand, and partly due to a need to expose students to more language across the curriculum. It appears that this trend towards more targetlanguage provision is driven by two forces: Firstly, the students who are asking for greater immersion in the target language, and secondly, academic staff who recognize that greater exposure to the L2 makes pedagogical sense.

\footnotetext{
${ }^{5}$ The term đ́ontent moduleódescribes those elements of the German undergraduate curriculum which are not dedicated specifically to language acquisition, but to topics such as German politics and society, history, literature, film, etc.
} 
However, at least on the tutor side, there are reservations: Respondent \#4, for example, cautions that,

[t]here are concerns, however, that [L2 content teaching] might limit the depth of material and quality of class discussion that can take place. We might initially trial a 'half-way-house', i.e. teaching some classes in Germany [sic] and some in English and similarly having some assignments in German and some in English.

This is an argument often heard during discussions about target-language teaching. Sceptics can generally be convinced of CLIL $\hat{\Phi}$ ability to enhance language skills through increased exposure to the L2. However, doubts about its validity as an effective method to develop content knowledge are more difficult to dispel, despite ample evidence from research in secondary education settings which supports this claim. Still, it cannot be denied that some examinations of CLIL contexts, especially in European higher education settings, point a spotlight at problematic aspects such as problems with lecture comprehension in Englishmedium instruction found in recent studies in Sweden and Norway (Pérez-CaŔado 2012, p. 322). A number of studies have also drawn attention to losses perceived by university students, such as increased use of avoidance strategies and heavier study load (cf. Aguilar \& Rodríguez 2012, pp. 184-5). Rather than taking such findings as confirmation of inherent flaws in CLIL as a teaching approach, Pérez-CaŔado (p. 322) considers them a valuable resource, as they provide ñpotentially revealing insights [...] which should be addressed in course design and which affect honing the language skills of these students and ensuring effective lecturing behavior on the part of professorsò

\section{L2 content teaching in the curriculum}

Moving on to question Q7, the data reveals that $L 2$ content teaching becomes more widespread with each year of study: Where $53 \%$ of respondents report that their German programmes contain content teaching in German in Year 1, the percentage increases to $74 \%$ in Year 2 and $79 \%$ in Year $F$ (Final Year).

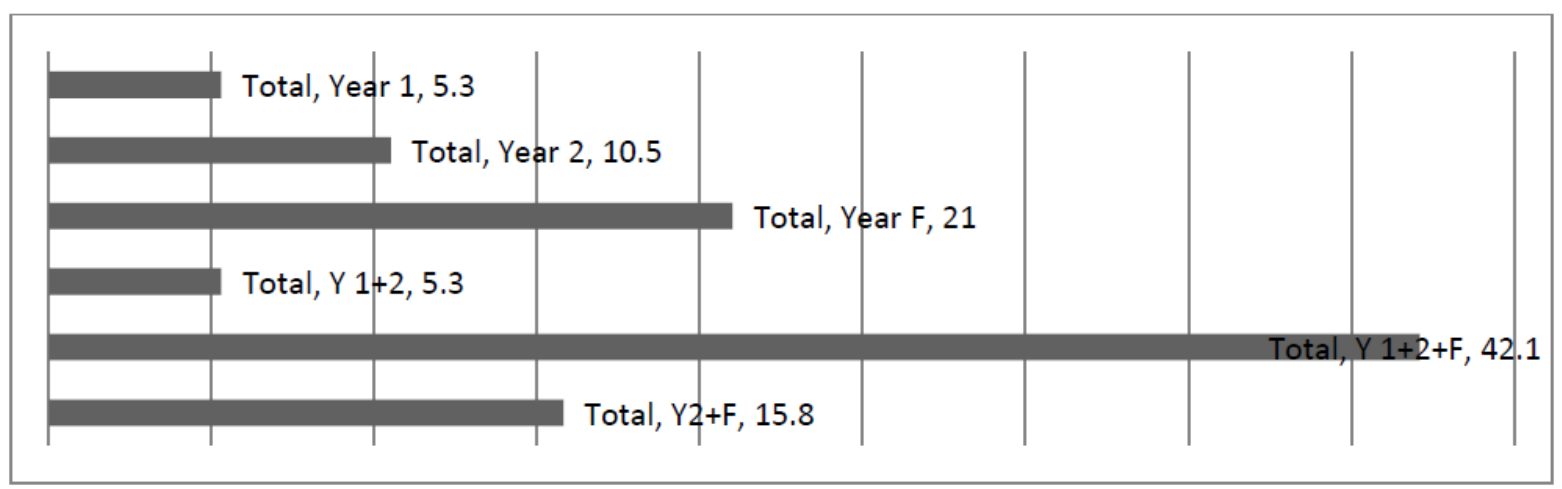

Fig. 2: Question 7, r̃At which programme level does target-language content teaching take place?ò 
Looking at the numbers in more detail, we find that, of the 19 institutions who provided information in this rubric, $42 \%$ provide $\mathrm{L} 2$ content teaching in all three programme years, whereas $47 \%$ only feature CLIL-type provision in Years 2 and/or $F(21 \%$ of them only in Year F). There may be a number of reasons for introducing CLIL later in the programme:

1. Students are expected to develop more advanced language skills during their first year of study before they follow a more L2-heavy study programme in Years 2 and F.

2. In order to prepare their students for the immersive experience of the Year Abroad, German departments increase exposure to the L2 in Year 2.

3. Once students return from their Year Abroad, they are keen to maintain and further enhance their improved language skills through continuing exposure to German.

If we correlate questions Q4 (mandatory Year Abroad) and Q5 (content modules taught in German) to determine whether an obligatory sandwich year spent studying or working abroad may be a significant factor in the decision to teach content in the L2, we find that the difference is minimal: Of those institutions which send their students abroad, 70\% have L2taught content modules, compared to $60 \%$ of those who do not mandate a Year Abroad. There is a slight difference in timing, however: Departments with sandwich programmes tend to start L2 content instruction in Year $1(63 \%)$, with provision increasing equally in Years 2 and $F(81 \%)$, whereas those which feature no mandatory study or work abroad provide no target-taught subject instruction in Year 1.

Type of content taught through the L2

Regarding the type of content taught in German, the most common modules concern politics and society $(67 \%)$, followed by literature $(61 \%)$, area studies $(56 \%)$ and history $(44 \%)$. Less frequently taught in the L2 are film (39\%), economics (33\%), and linguistics (28\%). ${ }^{6}$ In addition, in the rubric @́therô respondents also mentioned media and business.

A closer analysis of the data shows that the range of modules taught in German differs when we compare older with younger universities. In the latter group, all respondents which provided details in this rubric say that politics modules are taught in German, followed by literature and area studies (83\%), economics (67\%), film (50\%) and history and linguistics (33\%). In Ancient and Red Brick universities, politics and literature, along with history, are also most frequently taught in German, but only by $50 \%$ of respondent institutions. The numbers indicate that while the overall range of modules is the same, the number of modules taught in German in each institution is higher among the younger universities.

\footnotetext{
${ }^{6}$ It is unclear from the survey data whether this distribution is the result of curriculum structures or whether, for example, linguistics is less often taught in the target language because it is deemed doo difficultôfor CLIL.
} 


\section{Summary and outlook}

This paper has shown that the UK modern languages landscape has undergone tumultuous changes in the past few decades. The majority of British pupils and students appear to have lost interest in learning modern languages, judging by the declining uptake in postcompulsory language education. Since MFL became optional post-14, ever fewer pupils pursue languages until A-level, which has had a clear knock-on effect on admission numbers in HE. Consequently, MFL departments have had to adapt to new conditions. Many face considerable institutional pressure to deliver cost-effective programmes, leading to increased cross-departmental and interdisciplinary teaching provision. Due to various factors, including changing student expectations, curricula have been redesigned to reflect a stronger focus on broader contemporary socio-cultural themes.

With regard to ICL, the practice of teaching subject-specific content in the target language appears to be more wide-spread than previously thought. The findings presented here paint an interesting, in some ways surprising picture of the current extent of CLIL-type provision in German departments at British universities. We have seen that, contrary to popular belief, content provision in the $\mathrm{L} 2$ is actually quite common, but that younger universities are more likely to feature target-language content teaching. Whether or not a German programme features a mandatory sandwich year has little influence on the presence of CLIL-type content provision; however, programmes that do send their students abroad in their third year are more likely to introduce the L2 in content modules in Year 1 rather than later. On the whole, British institutions provide a wide range of subjects in German, but the volume of L2-taught content is greater among the younger universities.

The text commentaries allow some insights into the reasons for and against introducing L2taught content modules: On the one hand, financial pressures have become an incentive to provide more cross-disciplinary content in English. On the other hand, some universities report that they are discussing the introduction of German-taught content modules, or have already done so, because their students demand it, or because they feel that it makes sense from a pedagogical perspective.

As mentioned earlier, the findings presented here provide the macro-context for the case study at the heart of a larger project which will analyse the implementation of integrated content and language instruction in the German programmes of a Plate Glass university in the West Midlands, based on quantitative and qualitative data gathered from undergraduate German students and instructors. Like all educational settings, the institution at the heart of this larger study represents a specific social, cultural and political context, influenced by a multitude of factors, including university policy, institutional learning and teaching frameworks, individual teaching practices, the makeup of the student body, and so on. It will be particularly interesting to analyse the interplay between the local context at this particular 
university and the broader implications of recent developments in MFL education at the tertiary level which were discussed here. 


\section{References:}

Aguilar, M. \& Rodríguez, R. (2012). Lecturer and student perceptions on CLIL at a Spanish university. International Journal of Bilingual Education and Bilingualism, 15(2), 183-197.

Coleman, J. A. (1996). Studying languages. A survey of British and European students. London: Centre for Information on Language Teaching and Research (CILT).

Coleman, J. A. (2004). Modern Languages in British Universities: Past and Present. Arts \& Humanities in Higher Education, 3(2), 147-162.

Coleman, J. A. (2006). English-medium teaching in European Higher Education. Language Teaching, 39(1), 1-14

Costa, F. (2009). ICLHE/ CLIL at the Tertiary Level of Education. State-of-the-Art. Studies About Languages (Kalbd Studijos), 15, 85-88.

Footitt, H. (2005). The National Languages Strategy in Higher Education. Research Report No. 625. Southampton: LLAS. Retrieved from Fehler! Hyperlink-Referenz ungültig.

Gieve, S. \& Cunico, S. (2012). Language and content in the modern foreign languages degree: a studentsôperspectiveò The Language Learning Journal, 40(3), 273-291.

Grix, J. \& Jaworska, S. (2002). Responses to the Decline in Germanistik in the UK. German as a Foreign Language, 3, 1-24.

Gustafsson, M., Eriksson, A., Räisänen, C., Stenberg, A-C., Jacobs, C., Wright, J., WyrleyBirch, B., \& Winberg, C. (2011). Collaborating for content and language integrated learning: The situated character of faculty collaboration and student learning. Across the Disciplines, 8(3). Retrieved from http://wac.colostate.edu/atd/clil/gustafssonetal.cfm.

Kelly, M. \& Jones, D. (2003). A new landscape for languages. A report commissioned by the Nuffield Foundation. London: The Nuffield Foundation.

Klapper, J. (2006). Understanding and developing good practice. Language teaching in higher education. London: CILT.

Kolinsky, E. (1994). Ergebnisse einer empirischen Untersuchung zu Stand und Entwicklung der Germanistik in Großbritannien. InfoDaF, 21(1), 25-44.

Macías, I. (2006). Case Study: Lecturing in the target language to post A level Spanish students: linguistic gains and pedagogical implications. LLAS Good Practice Guide. Southampton: LLAS. Retrieved from http://www.llas.ac.uk/ resources/gpg/2482

McBride, N. (2003). The Role of the Target Language in Cultural Studies: Two Surveys in UK Universities. Language, Culture and Curriculum, 16(3), 298-311.

Mulkerne, S. \& Graham, A. M. (2011). Labour Market Intelligence on Languages and Intercultural Skills in Higher Education. Southampton: UCML. Retrieved from 
http://www.ucml.ac.uk/sites/default/files/shapingthefuture/101/17\%20\%20Anne\%20Marie\%2 0Graham\%20emp\%20resource\%20template 0.pdf

Nuffield Foundation (2000). Languages: the next generation. The final report and recommendations of the Nuffield Languages Inquiry. London: The Nuffield Foundation. Retrieved from http://www.nuffieldfoundation.org/sites/default/files/languages final report.pdf

Pérez-CaŔado, M. L. (2012). CLIL research in Europe: past, present, future. International Journal of Bilingual Education and Bilingualism, 15(3), 315-341.

Reershemius, G. (2010). Deutsch in Großbritannien. In H.-J. Krumm, C. Fandrych, B. Hufeisen, \& C. Riemer (Eds), Deutsch als Fremd- und Zweitsprache. Volume 2. (pp. 1674ї 1680). Berlin: de Gruyter.

Tamponi, A.R. (2005). Content and language integrated university course: A task-based approach. Southampton: LLAS. Retrieved from http://www.llas.ac.uk/resources/paper/2295

Tinsley, T. \& Han, Y. (2012). Language Learning in Secondary Schools in England. Findings from the 2011 Language Trends survey. Reading: CfBT Education Trust. Retrieved from http://cdn.cfbt.com/ /media/cfbtcorporate/files/research/2012/r-language-learning-insecondary-schools-in-england-language-trends-2012.pdf

Tinsley, T. \& Board, K. (2013). Languages for the Future. Which languages the UK needs most and why. London: British Council. Retrieved from http://www.britishcouncil.org/ sites/britishcouncil.uk2/files/languages-for-the-future-report.pdf

UCAS (2012). Data reported for applications considered on time for 15 January deadline. Retrieved from http://www.ucas.com/about us/media enquiries/media releases/2012/2012 $\underline{0130}$

UCAS (2013). Report: 2013 cycle applicant figures - January deadline. Retrieved from http://www.ucas.ac.uk/ documents/stats/ 2013 applicantfigures jan additional.pdf

Worton, M. (2009). Review of Modern Foreign Languages Provision in Higher Education. London: Higher Education Funding Council for England (HEFCE). Retrieved from http://www.hefce.ac.uk/pubs/year/2009/200941/ 